\title{
Helping Students find the Right Track: A Partnership for Student Success
}

\section{Dr. Elizabeth Anne Stephan, Clemson University}

Dr. Elizabeth Stephan is a faculty member in the General Engineering Program at Clemson University. She earned B.S. and Ph.D. degrees in Chemical Engineering from the University of Akron, and worked as a Production Engineer at Dow Chemical in Traverse City, MI. She is the District Director for Tau Beta Pi and Chief Advisor for SC Alpha Chapter of Tau Beta Pi.

\section{Dr. Christine C Murphy, Clemson University Academic Success Center}

Dr. Murphy holds a Ph.D. in Plant Physiology and a BS degree in Math, both from Clemson University. She has served as the Special Programs Coordinator for the Academic Success Center at Clemson University since February 2007, with a leadership role for data analysis and assessment of ASC programs. She has 21 years of experience in the data processing and analysis field, and 14 years of experience in higher education. She coordinates the workshop program for the Academic Success Center, has taught the undergraduate university skills course to incoming students, and facilitates a graduate seminar course on BioComplexity. 


\section{Helping Students find the Right Track: \\ A Partnership for Student Success}

Clemson University combines the benefits of a major, land-grant, science- and engineeringoriented research university with a strong commitment to quality teaching and individual student success. Clemson is a student-centered community characterized by high academic standards, inclusiveness, collaboration and a drive to excel ${ }^{1}$.

The General Engineering (GE) Program at Clemson University is designed to introduce students to the various engineering disciplines from both an academic and professional prospective. All engineering students at Clemson begin their academic journey as a general engineering major and are required to complete a first year curriculum sequence before declaring their intended engineering major. This first year sequence includes two engineering courses, one in each semester.

Program Logistics

As students make the transition from high school or another college, they are often unaware of the requirements for success at a new institution. A program was developed to encourage use of the support services offered by the University and to promote academic engagement among first year GE students.

Starting in the fall of 2009, students enrolled in the first year engineering course sequence could earn up to $2 \%$ bonus on the final course grade by completing a variety of tasks centered on participation in academic support services and exploration of choosing a major. This program promotes "pro-active bonus", where students are taking part in support services before they begin to fail the course. It is different than "re-active bonus", the last minute desperation attempt by students to boost their grade in the final week of the course. Students must be participating in activities over the course of the entire semester to earn the full bonus credit. The two first-year courses in which the credit may be earned comprise 5 credit hours of the first-year typical 30 credit hour course load.

On the first day of the semester, students are presented with a list of activities they are allowed to complete to earn bonus credit. Each activity is worth $0.25 \%$ of the overall grade; students can complete up to 8 activities in a semester. This list includes workshops, guest speakers, and activities designed to help students improve study skills or explore different majors. Once an activity has been completed, the person in charge of the activity will sign under the "Verified" location, and the students will turn in the worksheet in class. An example of the worksheet is shown in Table 1.

Table 1. Example of bonus opportunities in Fall 2012. 


\section{September 2012 BONUS OPPORTUNITIES}

\begin{tabular}{|c|c|c|c|c|}
\hline $\begin{array}{l}\text { Date } \\
\text { Time }\end{array}$ & Tiłle & Verified & Type & Instructions \\
\hline $\begin{array}{c}9 / 4 \\
5: 00-6: 30 \\
\text { Holtz } \\
\text { Project Lab }\end{array}$ & $\begin{array}{l}\text { CoES Student } \\
\text { Organizations Fair }\end{array}$ & & $\begin{array}{l}\text { Drop In } \\
\text { Meet and } \\
\text { Greet }\end{array}$ & $\begin{array}{l}\text { Want to get involved in a science or engineering student organization } \\
\text { this year? Stop by the project lab and talk to some upperclassmen in } \\
\text { clubs and organizations in the College of Engineering and Science. } \\
\text { No registration is required for this event. }\end{array}$ \\
\hline $\begin{array}{l}9 / 17 \\
6: 00-7: 00\end{array}$ & Boeing Seminar & & Seminar & $\begin{array}{c}\text { Come here from a representative from Boeing, Charleston to learn about } \\
\text { working as an engineer in industry. } \\
\text { Register at: https://www.surveymonkey.com/s/GEBoeingseminar }\end{array}$ \\
\hline $\begin{array}{c}9 / 4 \\
4: 30-6: 00\end{array}$ & $\begin{array}{l}\text { Finding Your Career } \\
\text { Path }\end{array}$ & & \multirow{5}{*}{$\begin{array}{l}\text { ASC } \\
\text { Workshop }\end{array}$} & \multirow{5}{*}{$\begin{array}{l}\text { After attending the workshop, have the ASC } \\
\text { workshop leader sign in the "VERIFIED" column. }\end{array}$} \\
\hline $\begin{array}{c}9 / 5 \\
4: 00-5: 00\end{array}$ & $\begin{array}{l}\text { This is a Test...This is } \\
\text { Only a Test }\end{array}$ & & & \\
\hline $\begin{array}{c}9 / 6 \\
12: 30-1: 20\end{array}$ & The Art of e Learning & & & \\
\hline $\begin{array}{c}9 / 6 \\
12: 30-1: 20 \\
\end{array}$ & $\begin{array}{l}\text { Study Smarter } \\
\text { Strategies }\end{array}$ & & & \\
\hline $\begin{array}{c}9 / 6 \\
5: 00-6: 00\end{array}$ & $\begin{array}{c}\text { Executive Functioning: } \\
\text { What's That? }\end{array}$ & & & \\
\hline
\end{tabular}

Two very popular activities are the "CoES Student Organizations Fair" and "Alumni and Major Mix and Mingle." In the Organizations Fair, the various clubs and organizations in the college are allowed to set up tables and displays in a ballroom. Students can explore the various opportunities to get involved in activities, and are required to talk with three different organizations to receive credit. For the Mix and Mingle, each engineering field is represented by faculty, alumni and upperclassmen at stations set up around a large room. Students mingle and ask questions about classes, co-op, research opportunities, and student organizations. This provides students a casual atmosphere to talk student-to-student with juniors and seniors in the various engineering majors, and ask the alumni how they choose their major and what their major is really like in the "real world. Students must "mingle" with two different departments to receive credit.

\section{Student Participation}

The majority of the opportunities are workshops offered by the Academic Success Center (ASC). The ASC at Clemson University offers workshops, supplemental instruction, tutoring, a university skills course, academic coaching and counseling to academically engage students. Previous data compiled by the ASC indicates a statistically significant increase in classroom performance, freshmen to sophomore retention rates, and scholarship retention by students who use academic support services ${ }^{2}$.

Workshop topics include note-taking, speed reading, test-taking, stress management, time management, preparation for finals, managing test anxiety, along with other motivational and academic skills topics. The percentage of students participating in the bonus program and the average number of workshops attended increased from Fall 2009 to Fall 2012, as shown in Figures 1 and 2. Since the program began, 39\% of the enrolled students in these courses have participated in the bonus option by attending at least one workshop, with the average number of 
workshops attended in a semester being 3.4. For the two years prior to the bonus option being introduced, only $2.2 \%$ of the general engineering majors attended a workshop, with the average attendance being 1.5 workshops attended.

Participants completed evaluations at the end of each workshop. Over the past 3 years, attendees rated the usefulness of the workshop information at 4.21 (Likert scale: 1 strongly disagree, 5 strongly agree), and the facilitator's presentation at 4.72. For the Fall 2012 semester, 98\% of attendees plan to use strategies presented in the workshop, and $96.4 \%$ would recommend the workshop to a friend.

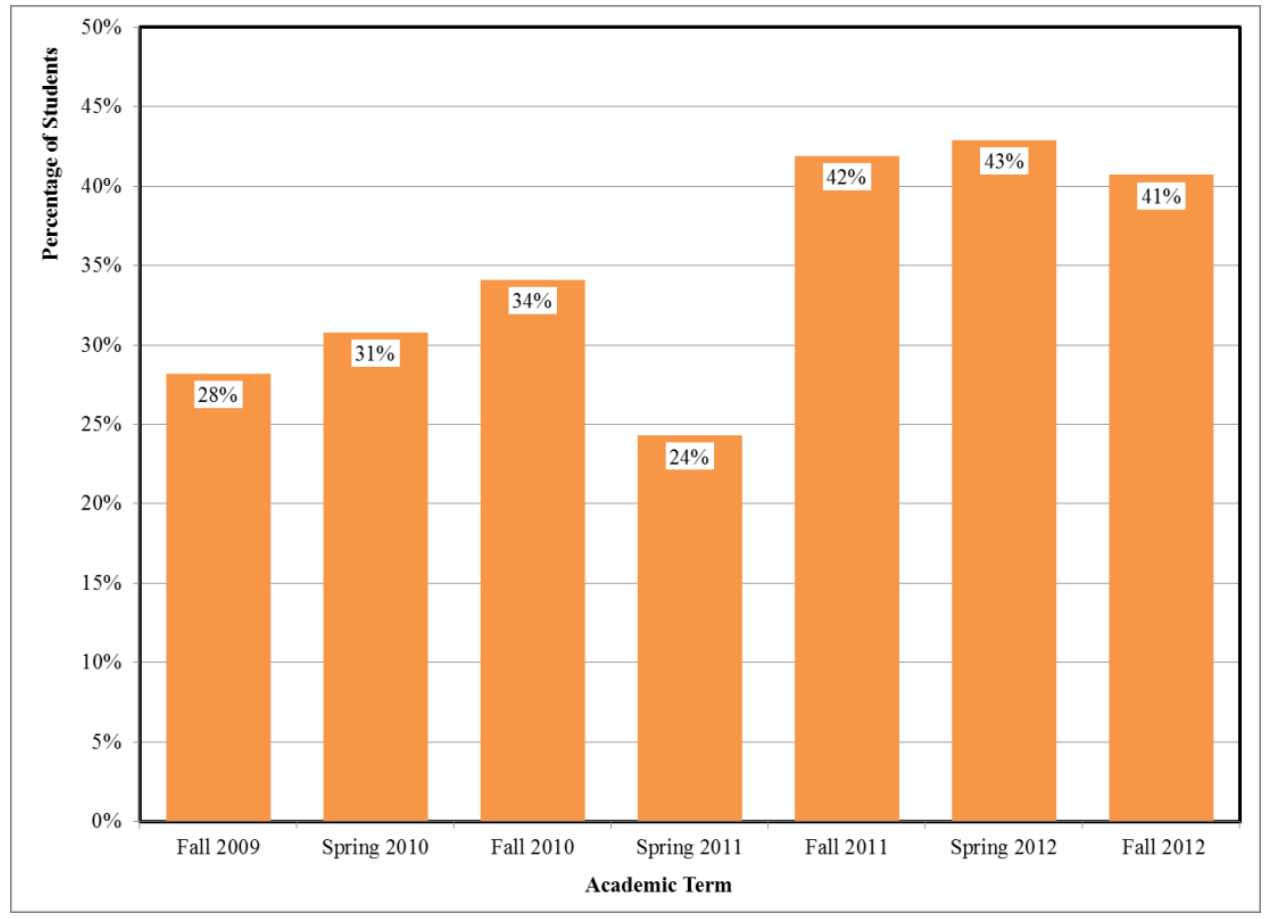

Figure 1. Percentage of students who participated in ASC workshops during first-year engineering courses. 


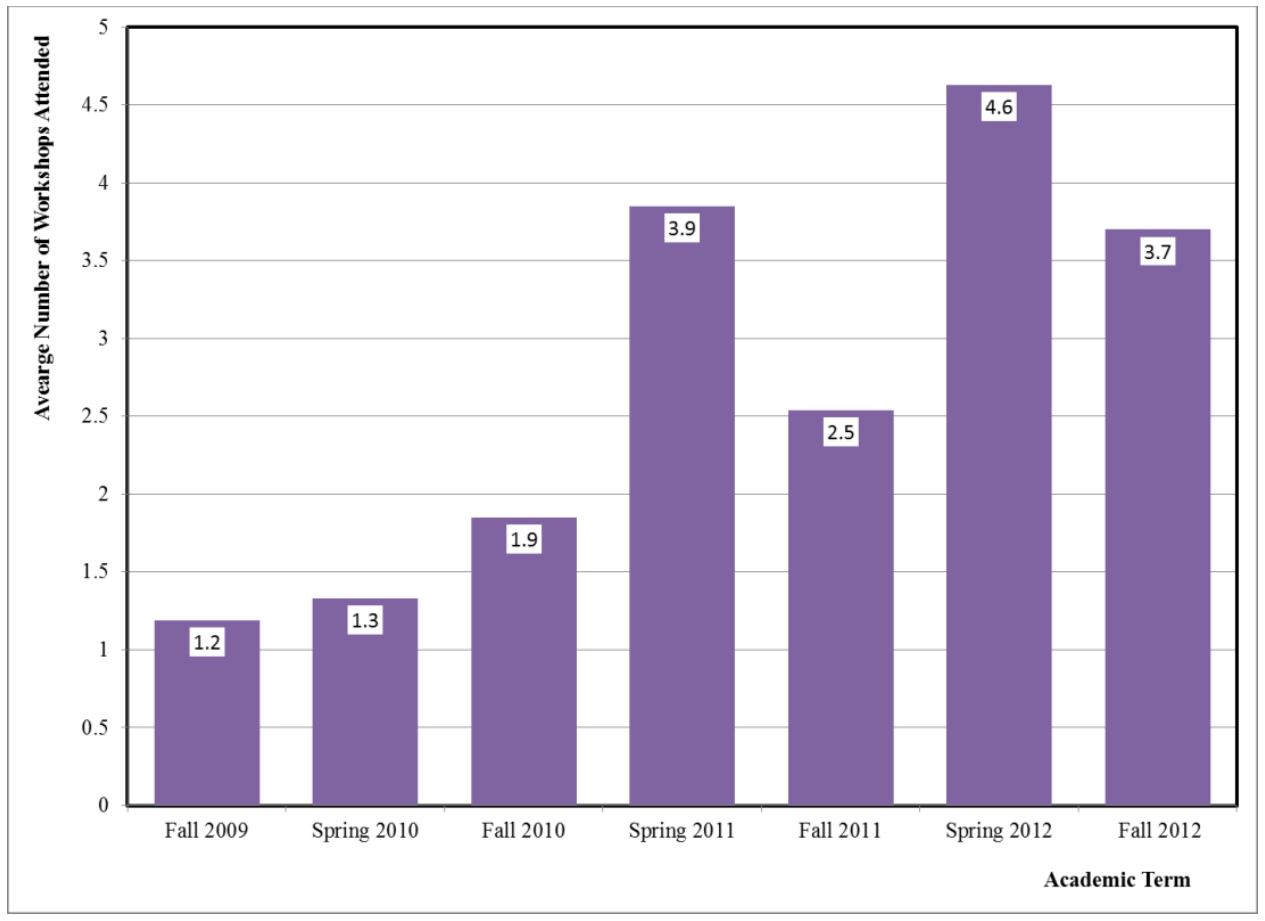

Figure 2. Average number of workshops attended by students during first-year engineering courses.

Impact on Grades and Retention

Since the inception of this program, the ASC has seen a large increase in the number of students participating in workshops. In Fall 2011, GE students accounted for two-thirds of the unique workshop participants and over $80 \%$ of the attendance in the success center's workshop program. Prior to the introduction of the bonus option, general engineering students accounted for $10 \%$ of the workshop participants. Students who attended a workshop outperformed those students not engaging in the bonus option in their general engineering classes and in their semester grade point ratios (GPR), as shown in Table 2. The differences were found to be statistically significant, using a 2-sample heteroscedastic T-test with $\alpha=0.05$.

Table 2. Course grades and semester GPR for students who participated in the bonus opportunities versus students who did not attend any ASC workshops for students enrolled in first-semester engineering course.

\begin{tabular}{|l|c|c|c|}
\hline & CES 102 Course Grade & Semester GPR & n \\
\hline \multicolumn{2}{|c|}{ Fall 2011 (n=955, 2.5 workshops attended on average, $\boldsymbol{p}<0.00001)$} \\
\hline Participated in workshops & 2.96 & 3.21 & 407 \\
\hline Did not participate & 2.68 & 2.76 & 548 \\
\hline Difference in outcome & 0.28 & 0.45 & \\
\hline \multicolumn{2}{|c|}{ Fall 2012 (n=1181, 3.0 workshops attended on average, $\boldsymbol{p}<\mathbf{0 . 0 0 0 0 1 )}$} \\
\hline
\end{tabular}




\begin{tabular}{|l|l|l|l|}
\hline Participated in workshops & 3.13 & 3.31 & 406 \\
\hline Did not participate & 2.37 & 2.75 & 775 \\
\hline Difference in outcome & 0.76 & 0.56 & \\
\hline
\end{tabular}

Students in the first semester general engineering course Fall 2012 who engaged in the bonus option and attended one or more workshops did significantly better than students who did not participate. When examining the number of workshops that were most significant for improved performance, students attending more than 2 workshops had the best outcome for the course grade, and students attending 8 workshops had the best outcome for semester GPRs. The results are shown in Table 3 below.

Table 3. Comparison of number of workshops attended and impact on course grade in first semester general engineering course grade and semester GPR for Fall 2012.

\begin{tabular}{|c|c|c|c|c|c|}
\hline $\begin{array}{c}\text { \# Workshops } \\
\text { Attended } \\
\end{array}$ & n & $\begin{array}{l}\text { Course } \\
\text { Grade }\end{array}$ & $\begin{array}{c}\text { Semester } \\
\text { GPR }\end{array}$ & $\begin{array}{c}\text { Course Grade } \\
\text { ttest }\end{array}$ & $\begin{array}{l}\text { Semester } \\
\text { GPR ttest }\end{array}$ \\
\hline 0 & 775 & 2.37 & 2.75 & \multirow{2}{*}{$2.05406 \mathrm{E}-30$} & \multirow{2}{*}{$6.10517 \mathrm{E}-29$} \\
\hline$>0$ & 406 & 3.13 & 3.31 & & \\
\hline 1 & 166 & 2.91 & 3.18 & \multirow{2}{*}{0.000102} & \multirow{2}{*}{0.002578} \\
\hline$>1$ & 240 & 3.28 & 3.40 & & \\
\hline$>2$ & 189 & 3.34 & 3.44 & \multirow{2}{*}{$2.66961 \mathrm{E}-06$} & \multirow{2}{*}{0.000126024} \\
\hline$<=2$ & 217 & 2.94 & 3.20 & & \\
\hline$>3$ & 144 & 3.36 & 3.44 & \multirow{2}{*}{$2.16587 \mathrm{E}-05$} & \multirow{2}{*}{0.001870184} \\
\hline$<=3$ & 262 & 3.00 & 3.24 & & \\
\hline$>4$ & 111 & 3.36 & 3.45 & \multirow{2}{*}{0.000160069} & \multirow{2}{*}{0.000788766} \\
\hline$<=4$ & 295 & 3.04 & 3.26 & & \\
\hline$>5$ & 69 & 3.38 & 3.42 & \multirow{2}{*}{0.001844416} & \multirow{2}{*}{0.054617583} \\
\hline$<=5$ & 337 & 3.07 & 3.29 & & \\
\hline$>6$ & 38 & 3.47 & 3.51 & \multirow{2}{*}{0.00134339} & \multirow{2}{*}{0.013980622} \\
\hline$<=6$ & 368 & 3.09 & 3.29 & & \\
\hline 8 & 14 & 3.71 & 3.74 & \multirow{2}{*}{0.000141951} & \multirow{2}{*}{$3.6415 \mathrm{E}-05$} \\
\hline$<=7$ & 392 & 3.10 & 3.30 & & \\
\hline
\end{tabular}

In examining the retention of students between 2009 and 2011, students remaining in engineering who engaged in the bonus option had higher cumulative GPRs (3.17 versus 2.93) than those who did not attend any workshops. For all general engineering students that engaged in the bonus option, the impact on cumulative GPR was greater for transfer students than it was for new freshmen. The difference in GPR becomes significant for in-state students, as almost all in-state students at Clemson have a state scholarship that requires a minimum 3.0 GPR to maintain each year. 


\section{Future Work}

One of the challenges is to get students to avoid procrastinating and to engage in the bonus option earlier in the semester. This allows for accrual of more bonus points by the student, a longer period of time for the skill to be practiced in that semester, and the possibility to attend workshops with a wider variety of topics. Many of the workshops offered the last week deal with tips for finals, and while each workshop offering is given by a different presenter and has a different method of presenting the material, students receive a less diverse set of academic skill building workshops than if they attended throughout the semester. In the upcoming semesters, workshops attended in the first month will be awarded double credit as compared to workshops attended later in the term. The success of this double reward concept will be monitored for impact on student success. Additionally, targeted qualitative follow up with participants will be conducted to determine what skills and techniques the student reports using as a result of the workshop.

Conclusion

Most schools have many resources available to incoming and continuing students, and data to support that those students who utilize the resources have better outcomes. However, many students do not utilize these resources. The use of this "proactive" bonus option in the general engineering courses provides a small, positive incentive for utilizing school resources, and the students are achieving better outcomes in the course and in their semester grades. The faculty requirement is minimal to implement this program. As a suggested starting point, faculty should arrange to meet with their campus success center director to discuss the possibility of partnership.

\section{Bibliographic Information}

1. www.clemson.edu

2. C. Murphy and E. Stephan, "Collaborations to Get General Engineering Students on the Right Track," NCLCA, Charlotte, NC, September 2010. 